\title{
Over-the-counter (OTC) medicines - an alternative in the fight against pain in the opinion of medical university students
}

\author{
EDYTA KRZYCH-FAŁTA*, BOLESŁAW SAMOLIŃSKI
}

Department of Prevention of Environmental Hazards and Allergology, Faculty of Health Sciences, Medical University of Warsaw, Poland

\begin{abstract}
The purpose of this study was an attempt to answer the question whether, in the opinion of the students of the Medical University of Warsaw, it is justifiable and necessary to use the so-called over-the-counter medicines. The subjects in the study included a homogeneous group of 102 people aged 20-24 years living in urban areas. The method used in the study was a survey questionnaire, which was filled out by each individual subject. There are definitely more subjects (76\%) who, in case of pain, do not take OTC medicines. A very small percentage of respondents read the leaflet that comes with the medicine and $63 \%$ of them are of the opinion that medicines available over the counter are safe. More than a half of the respondents (79\%) say that they take non-prescription medicines more often because of their easier availability (e.g. at grocery shops or petrol stations).
\end{abstract}

Keywords: Over-the-counter medicines, questionnaire

\section{INTRODUCTION}

The market in over-the-counter medicines (OTC) has been enjoying a revival following the change in legal regulations, which took place in 1994 allowing the advertising of medicines in the public media [2, 3, 18]. Average expenditure on pharmaceuticals in Poland is about $16 \%$ of the total health care $[13,14]$. Making the decision to opt for "self-medication" the Polish society largely exposes itself to a multitude of adverse drug reactions due to either lack of knowledge, influence of advertising or simply disregard of the information about the possible adverse drug reactions contained in the leaflet accompanying the pharmaceutical drugs [15]. Another important factor in the current situation seems to be health education [1]. Despite the fact that the contributing factor to the increase in sale of non-prescription medicines has been the growing number of supermarkets, and accessibility of the drugs at petrol stations, nowadays majority of these medicines are sold in pharmacies (in accordance with the regulation of the Minister of Health of September 2010 only the OTC

\footnotetext{
Corresponding author

* Department of Prevention of Environmental Hazards and Allergology, Faculty of Health Sciences, Medical University of Warsaw,

Banacha 1a str., 02-097 Warsaw, Poland e-mail

e.krzych@gmail.com
}

medicines based on 52 active ingredients may be sold in non-pharmacy outlets: in shops, petrol stations, newsstands, chemists, etc.) [12]. According to WHO, the share of income of the pharmaceutical companies related to the market for non-prescription drugs comes to an average of $25 \%-34 \%[7,12,9]$. This explains why the most efficient forms and channels of communication (advertising) are being used to "cater the needs of the society" $[4,6,7,16]$. According to TNS, customer buys a fifth of medicines outside pharmacies and about $31 \%$ of Poles are buying drugs under the influence of advertising [15].

\section{AIM}

The aim of this study was an attempt to answer the question whether, in the opinion of the students of the Medical University of Warsaw, it is justifiable and necessary to use the so-called OTC medicines.

\section{MATERIAL AND METHODS}

The subjects in the study were a homogeneous group of 102 people (women undergraduate students of nursing) aged 20-24 years living in urban areas. The method used in the study was a survey questionnaire which was filled out by each individual subject. 


\section{RESULTS}

There are definitely more subjects (76\%) who, in case of pain, do not take OTC medicines. A very small percentage of respondents read the leaflet that comes with the medicine and $63 \%$ of them are of the opinion that medicines available over the counter are safe. More than a half of the respondents (79\%) say that they take non-prescription medicines more often because of their easier availability (e.g. at grocery shops or petrol stations).

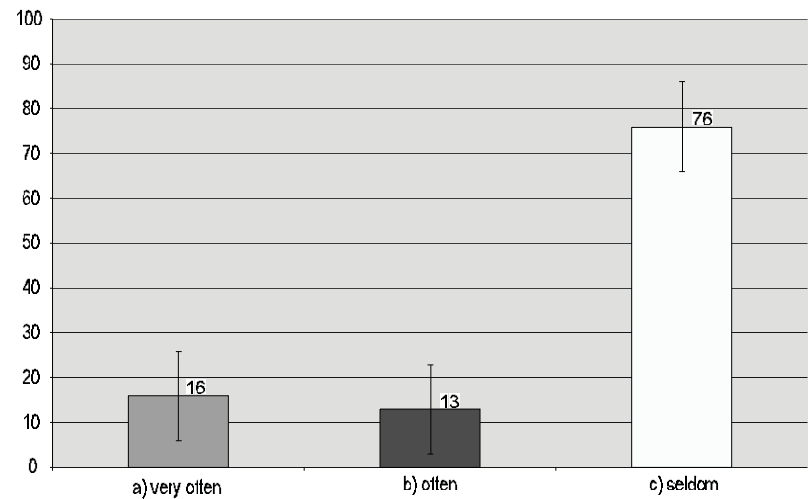

Fig. 1. How often do you use OTC medicines to relieve pain?

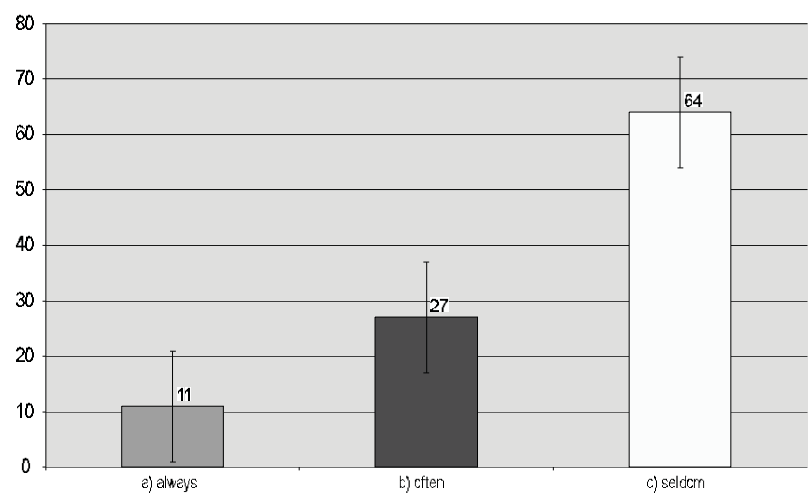

Fig. 2. Do you read the information contained on the leaflet carefully before taking an OTC medicine?

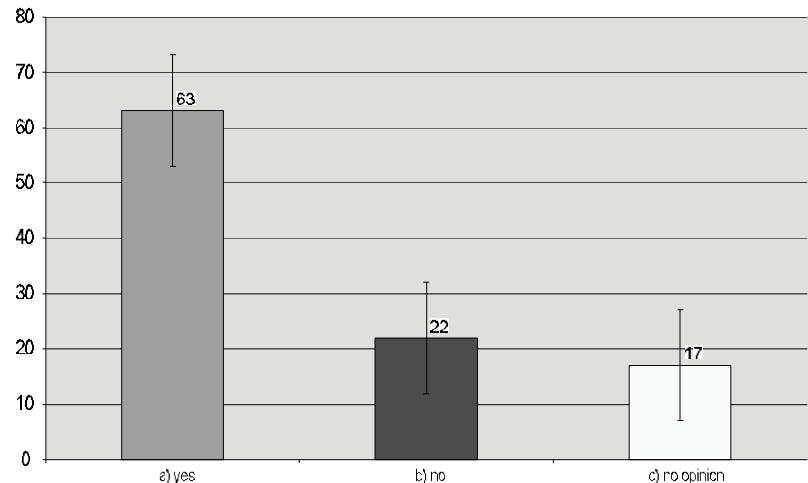

Fig. 3. Do you believe OTC medicines are safe?

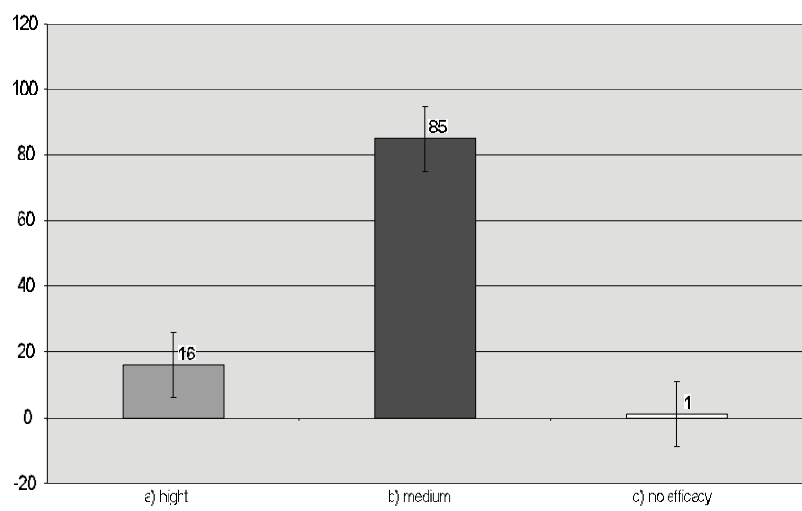

Fig. 4. How would you rate the efficacy of OTC medicines with respect to pain, infection, etc.?

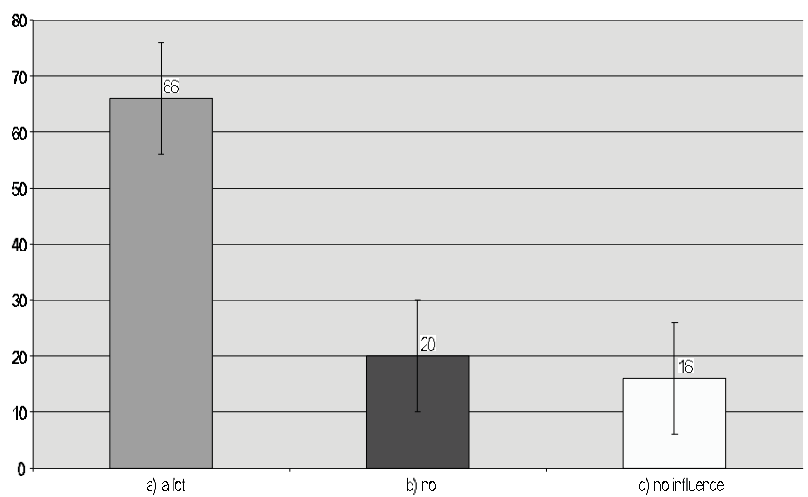

Fig. 5. How much influence does advertising have on the use of OTC medicines?

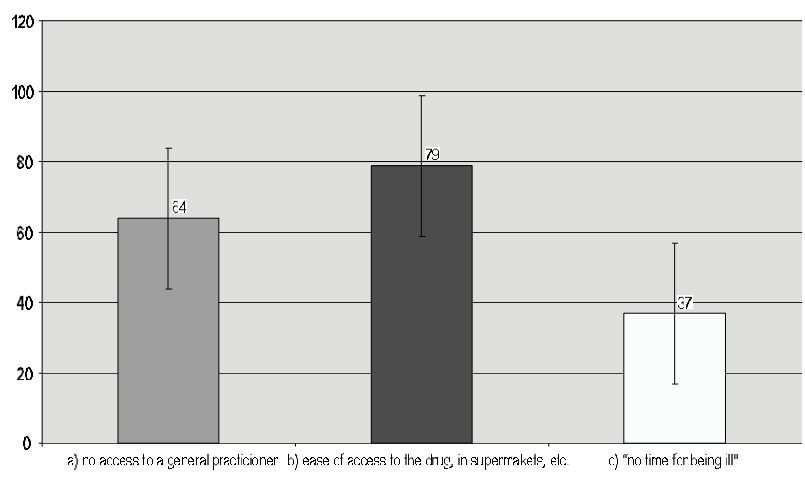

*multiple-choice question

Fig. 6. In your opinion, what is the reason of using OTC medicines?

\section{DISCUSSION}

Very few respondents admit using OTC medicines to relieve pain, which is largely dictated by the ease of access to these pharmaceuticals as well as the lack of time "for staying ill". According to the information of the Polish Central Statistical Office (GUS), only $2 \%$ of all respondents do not take the medicines, which clearly indicates the immense popularity of this group of medicines $[11,15]$. The increase in sale of the OTC medicines is not only caused by their wide availability and the limited ac- 
cess to specialist medical advice. Another contributing factor is the improving economic situation of the population. The information gathered by the Institute for Social Research of the Healthcare Information Systems Centre (CSiOZ) indicates that the most often purchased nonprescription medicines are the pain relievers and antiinflammatory medicines $-57 \%$, cold relievers $-19.5 \%$, and, finally, vitamins and minerals - 13.5\% [8].

In the current research study, the respondents rating the efficacy of the taken medicines emphasized mainly the qualities related to pain relief and the high level of safety, in combination with complete unawareness of the adverse drug reactions detailed in the medication leaflet (this group of respondents was professionally connected with medicine). Paradoxically, respondents not professionally connected with medicine, always read the medication leaflet $-70 \%$, read it sometimes $-19 \%$. Opinions of the respondents with regard to the harmful effects of these medications have been split: $20-30 \%$ of the respondents decided that the OTC medicines definitely produce negative effects on our health and are dangerous, while $34 \%$ declared the opposite $[8,11]$. The informal label for the OTC medicines - "a wolf in sheep's clothing", has been coined for a reason. A negative influence on organs, mainly kidneys and liver, has been observed and related not only to overdosing on these medicines but also to systematic use following the directions from the manufacturer.

The participants of the current research project pointed to the high level of influence of advertising on their decisions to buy and the choice of non-prescription medicines. On the contrary, a research study conducted in 2007 indicated that advertising was at the bottom of a list as a motivating factor for the choice of "self-medication" [5,9] with $20 \%$ of respondents, preceded by earlier usage of the same product $-83 \%$, advice from a pharmacist $67 \%$, advice from a doctor $-60 \%$, cost of the medication $50 \%$, advice from a friend $-49 \%$. Additionally, $38 \%$ of the respondents do not trust the advertising for nonprescription medicines very much, and $38 \%$ do not trust it at all $[8,10]$. Advertising slogans like: "the maximum power in a single dose", or "the number 1 flu remedy in the world" often target our emotions, and by using different tools of marketing communication $[13,17]$ in their messages, the manufacturers achieve their pre-defined aim - an increase in sales; all in compliance with the Code of Pharmaceutical Marketing Ethics [14]. According to a 2003 research report, the highest level of brand awareness was achieved by Paracetamolum and Ibuprofenum thanks to the major source of information which is television advertisement $[10,12]$.
Bearing in mind the many reasons for considerate choice of medication and self-medication - do "always read the leaflet enclosed in the packaging, or ask your doctor or pharmacist for more information as any medicine taken incorrectly may endanger your life or health".

\section{REFERENCES}

1. Bażydło M. et al.: Analiza stosowania leków OTC bez konsultacji z lekarzem w poszczególnych grupach wiekowych oraz ocena zapotrzebowania na edukację zdrowotną w tym zakresie. Fam. Med. Prim. Care Rev., 12, 127, 2010.

2. Czupryna A., Piździoch S., Ryś A. (2001): Zdrowie publiczne. Wybrane zagadnienia. Tom II. Vesalius, 115-118.

3. Chomont K., Grzebieluch J.: Analiza procesów kształtowania cen leków na rynku farmaceutycznym w Polsce część I. Piel. Zdr. Publ., 1, 353, 2011.

4. Kotler P. (1994): Marketing. Analiza, planowanie, wdrażanie i kontrola, Gebethner\&Ska; p. 161.

5. Kurczewska U.: O samoleczeniu i lekach bez recepty. Farm. Pol., 61, 8,395, 2005.

6. Macewicz H. (2010): Przejawy manipulacji w formowaniu afektywnego komponentu postawy odbiorcy. Zeszyty Naukowe Polityki Europejskiej, Finanse i Marketing 3(52).

7. Michalik M., Pilarczyk B., Mruk H. (2008): Marketing strategiczny na rynku farmaceutycznym. Oficyna Wydawnicza Wolters Kluers business, Wyd II, p 159.

8. Pączkowska M. (2008): Raport z badań Korzystanie z leków i ich dostępność. Wydział Badań i Analiz Socjologicznych, p. 1-11.

9. Pęgiel-Kamrat J.E., Zarzeczna-Baran M.A.: Zjawisko samolecznienia wśród studentów pielęgniarstwa Akademii Medycznej w Gdańsku. Zdr. Publ., 114, 234, 2004.

10. Pilarczyk B..: Skuteczność reklamy leków OTC. Bez recepty. 3/2004.

11. Raport GUS (2007): Wydatki gospodarstw domowych na ochrone zdrowia, w: Ochrona zdrowia w gospodarstwach domowych w 2006 r., Informacje i opracowania statystyczne, GUS, p. 48.

12. Raport badań (2008): Rynek farmaceutyczny i ochrony zdrowia $w$ Polsce. PMR i Pharma Export.

13. Skrzypczak Z.: Zmiany poziomu i struktury wydatków w latach kryzysu gospodarczego. Probl. Zarzadz., 11, 1(40), t. 1, 88. 2013.

14. Szulc R., Buczek E. (2011): Dobra praktyka dystrybucyjna $w$ hurtowym ogniwie dystrybucji farmaceutycznej grupy kapitałowej. Farmacol. Zeszyty Naukowe WSZiM, p 10.

15. Synowiec J., Armatowski R..: Prawne aspekty działania przedsiębiorstw farmaceutycznych w kontekście Kodeksu Farmaceutycznej Etyki Marketingowej. Czas. Apt., 11, 6, 1999.

16. TNS OBOP, OTC drugs 2002. www.obop.pl

17. Ulatowska-Szostak E.: Wpływ reklamy na zakup leków, parafarmaceutyków i preparatów witaminowych w opiniach klientów aptek-porównanie w latach 2002-2007. Probl. Hig. Epidemiol., 89, 441, 2008.

18. Wdowiak L. et al.: Samoleczenie-kto kupuje OTC w Polsce? Zdr. Publ., 116, 578, 2006. 